\title{
THE WORLD YOUTH FESTIVAL AS A SOVIET CULTURAL PRODUCT DURING THE COLD WAR*
}

\author{
Pia Koivunen \\ University of Turku, \\ Turku, Finland
}

\begin{abstract}
This article discusses Soviet cultural diplomacy from the perspective of cultural production. It analyses a Soviet-sponsored international event, the World Festival of Youth and Students, as a cultural product created within the socialist system. The first festival was held in Prague in 1947, and the tradition continued throughout the Cold War period until today. Earlier scholarship has examined the festival as a propaganda tool, a forum for cross-cultural encounters, and a battlefield of the cultural Cold War between the capitalist West and the socialist East. Much has been written about individual world youth festivals and national delegations, while the design, cultural background and fundamental ideas behind the event have been much less acknowledged. By employing the concept of mega-event and comparing the festival with iconic international events, such as World's Fairs and the Olympic Games, it discusses the festival's composition and evolution, its reception, and how the event found its place in a world shaped by the tensions between the two social systems. It employs materials from the main organiser of the event, the World Federation of Democratic Youth, documents from the Communist Youth League (Komsomol) and the Communist Party of the USSR, and contemporary newspapers and magazines. The author argues that the USSR developed an attractive global cultural institution, which well suited the Cold War environment but was too dependent on financial support from the socialist bloc and too tied to the political agenda of the Soviet Union to become a universally accepted institution.
\end{abstract}

Keywords: World Youth Festival, mega-event, cultural production, cultural Cold War, WFDY, IUS, Komsomol.

Рассматривается советская культурная дипломатия как пространство производства культуры. В центре авторского анализа - Всемирный фестиваль молодежи и студентов, спонсируемое советской стороной международное событие, особый культурный продукт, созданный в рамках

* Citation: Koivunen, P. (2020). The World Youth Festival as a Soviet Cultural Product during the Cold War. In Quaestio Rossica. Vol. 8, № 5. P. 1612-1628. DOI 10.15826/qr.2020.5.548.

Цитирование: Koivunen P. The World Youth Festival as a Soviet Cultural Product during the Cold War // Quaestio Rossica. Vol. 8. 2020. № 5. P. 1612-1628. DOI 10.15826/qr.2020.5.548.

(C) Koivunen P., 2020

Quaestio Rossica • Vol. 8 • 2020 • № 5, p. 1612-1628 
социалистической системы. Проведение первого фестиваля в Праге в 1947 г. заложило традицию, сохранившуюся не только на протяжении всего периода холодной войны, но и пережившую ее. Всемирный фестиваль молодежи и студентов рассматривался организаторами как пропагандистский инструмент, форум для встреч представителей разных культур и поле битвы культурной холодной войны между капиталистическим Западом и социалистическим Востоком. В научной литературе значительное внимание уделено отдельным фестивалям и национальным делегациям, менее изученными до сих пор оставались дизайн, культурный фон и фундаментальные идеи, лежавшие в основе мероприятия. Используя концепцию мегасобытия и сравнение с признанными международными событийными площадками (всемирными выставками и Олимпийскими играми), автор анализирует специфику создания молодежного фестиваля, его восприятия различными аудиториями, а также его эффективность в соответствии с поставленными перед ним советской культурной дипломатией задачами. Источниковую базу статьи составили материалы Всемирной федерации демократической молодежи (главного организатора фестивалей), документы ВЛКСМ и КПСС, а также современные газеты и журналы. Сделан вывод о том, что СССР разработал привлекательный глобальный культурный институт, который хорошо подходил для условий холодной войны, но слишком зависел от финансовой поддержки со стороны социалистического блока. Тесная связь с политической повесткой Советского Союза помешала Всемирному фестивалю молодежи и студентов приобрести всеобщее признание.

Ключевые слова: Всемирный фестиваль молодежи и студентов, мегасобытие, производство культуры, культурная холодная война, Всемирная федерация демократической молодежи, Международный союз студентов, комсомол.

Soviet cultural diplomacy has recently been examined by a number of scholars who have enlightened us about the ways in which the USSR employed its cultural resources abroad and at home before and during the Cold War. Studies on tourism, cultural exchange, participation in mega-events, friendship societies, artistic tours and face-to-face interactions have shown how existing forms of culture and arts were harnessed for plans to influence foreign publics in favour of the socialist system [David-Fox; Applebaum; Babiracki]. Much of the research on the Soviet side in the cultural Cold War has focused on cultural activities and campaigns rather than on the inventive side of cultural diplomacy, in other words, the creation of new forms, structures and products in the culture and arts. This essay looks at Soviet cultural diplomacy from the perspective of cultural production [Griswold; Clarke].

In the spring of 1947, hundreds of youth and student associations around the world received an invitation to a brand new event that was going to take place in Prague, Czechoslovakia, next summer. According to its organizers, this event, the World Festival of Youth, aimed at giving "practical meaning 


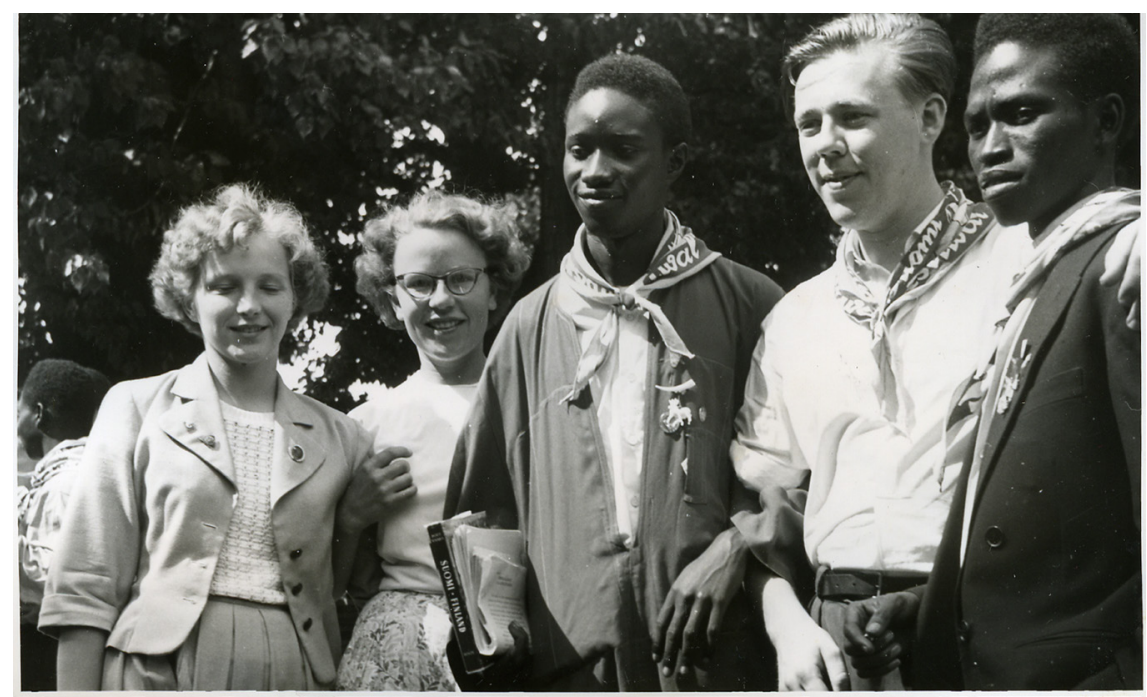

1. Warsaw festival 1955 // Labour Museum Werstas. Tampere, Finland

to the sincere desire of young people to learn about each other and build lasting friendship". They emphasised that the celebration was open to all young people from different national, ethnic, religious or political backgrounds and that it would provide a programme of all possible interests [Friendship News, p. 22]. Held two years after the end of World War Two, the Prague Festival of 1947 was immensely popular. 17,000 young people gathered to discuss visions of the future world and to dance, sing and have a good time after the dreadful years of total war. The Prague Festival became the first in a series of massive public celebrations that, during the post-war years, developed into a regularly organized international event and served as an arena for transsystemic communication, competition and struggle during the Cold War years.

The World Festival of Youth and Students (hence the World Youth Festival) has been called many things depending on the perspective. In the USSR, the festival was treated as a political mass event of the democratic youth movement, governed by the World Federation of Democratic Youth and the International Union of Students. The festival's peace agenda linked it to the World Peace Movement; sometimes, the series of festivals has been referred to as the festival movement [Мошняга]. During the Cold War years, Western scholars and journalists approached the event primarily in the context of Soviet foreign propaganda and Soviet-sponsored front organizations [Barghoorn, passim.]. Recent scholarship has widened the discussion of cultural, sexual and ideological exchange, youth culture and social movements, emphasising the festival as a bridge between East and West, North and South [Roth-Ey; Taylor; Koivunen; Rutter].

This paper analyses the World Youth Festival as a cultural product of the socialist system. Unlike much of the earlier research, which has focused on individual festivals and/or national delegations, this essay introduces an in- 


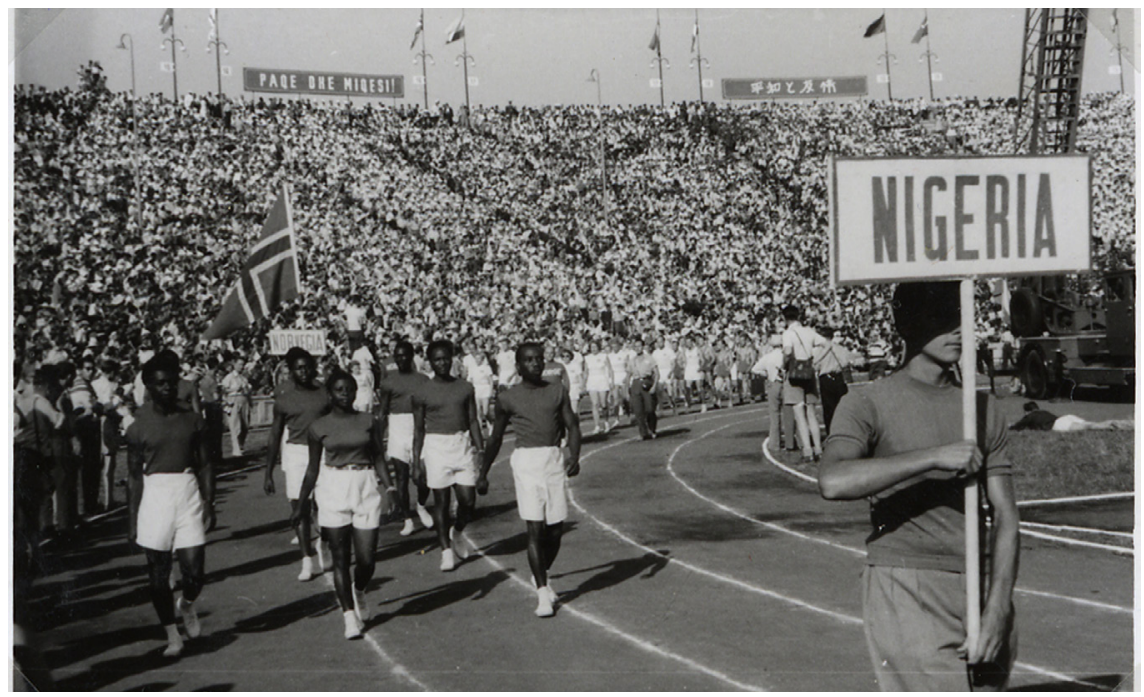

2. Bucharest youth festival 1953 // Labour Museum Werstas. Tampere, Finland

stitutional perspective. It discusses the design and development of the event, analyses its components and elaborates on its roots in different celebration traditions. It argues that the World Youth Festival was one of the most wellknown and successful cultural products of the USSR. In comparison with other international events of the socialist system, such as the Workers' Olympics (Spartakiads) or the Intervision Song Contest, the World Youth Festival was not an attempt to create a socialist alternative to an existing event from the capitalist world. The festival borrowed a lot from various contemporary celebration traditions and major international events, as we shall see the following sections, and these adopted elements together composed an original concept - a special event for the young generation.

This article is based on the archival collections of the World Federation of Democratic Youth, the Komsomol, the Anti-Fascist Committee of Soviet Youth (the Soviet member organization in the WFDY and the IUS until 1956) and contemporary media sources from the USSR, the US and the $\mathrm{UK}^{1}$. It approaches the World Youth Festival by employing the concept of a mega-event and compares it to two iconic international events, the World's Fairs and the Olympic Games².

${ }^{1}$ These materials are held in the Russian State Archive of Contemporary History (Pocсийский государственный архив новейший истории, РГАНИ) and the Russian State Archive of Socio-Political History (Российский государственный архив социльнополитической истории, РГАСПИ), as well as People's Archive (Kansan Arkisto) in Helsinki. The People's Archive's collection contains documents from the World Federation of Democratic Youth from the late 1940s and early 1950s.

${ }^{2}$ This article and its methodological approach is based on author's doctoral dissertation [Koivunen]. See also [Schiller; Попов], which both discuss individual World Youth Festivals in the context of mega-events. 
The field of event studies has thus far heavily focused on mega-events created within the Western world, while events born in the socialist world or in global south have merited much less attention. The Spartakiads and the Intervision Contest do get marginal mentions, but the World Youth Festival seems to be invisible in the multidisciplinary field that explores various international and global events, even though it clearly meets the criteria that scholars studying the subject have attached to the concept of a mega-event. To give a classic example, the sociologist Maurice Roche characterises mega-events as "large-scale cultural events which have a dramatic character, mass appeal and international significance". They are typically organised with governmental support and "can be said to be important elements in 'official' versions of public culture" [Roche, p. 1-32]. A more recent definition by the geographer Martin Müller consists of four key elements an event needs to qualify as a mega-event: visitor attractiveness, mediated reach, costs and transformative impact. While these four elements are crucially important factors in defining what mega-events are about, Müller's focus on quantitative requirements in terms of costs and the number of spectators leaves out practically all events before the emergence of television and thus underestimates their historical importance and evolution over time [Müller]. While recent scholarship on mega-events has widened to the post-socialist world, the history of hosting and creating events in the socialist world has received much less attention. This article wishes to widen the discussion on mega-events and their formation to the Cold War period and to events created within the socialist world.

\section{Introducing a new youth event in the aftermath of World War Two}

The World Youth Festival was a child of the World Federation of Democratic Youth - a Soviet-sponsored umbrella organization for youth associations. The idea of putting together a celebration for youth was suggested for the first time in the founding congress of the WFDY in London in OctoberNovember 1945, when the war had just ended and the relations between the USSR and the Western allies had not yet frozen [Kotek, p. 188-189]. The festival was one of the many activities of the WFDY, which started to organize regional and local meetings on youth rights and social issues, youth camps and exchanges for working-class youths in Europe and in the colonial world in Asia and Latin America. The World Youth Festival, however, proved to be the most attractive and popular. During the early Cold War years, with festivals in Prague (1947), Budapest (1949) and Berlin (1951), it evolved into a recognisable concept, which became acknowledged among its supporters and adversaries. In 1951, another Soviet-supported organization, the International Union of Students (IUS), founded in 1946, joined forces with the festival and the name of the event took its final form.

The World Youth Festival was a new kind of youth event, one which sought to gather the world's young generation to meet each other and foster friendly relations between nations. The thinking behind the festival was 
based on the same idea that had brought countries together to establish the United Nations. In comparison with other international youth and student meetings of that time, such as the Scout Jamboree or the Student University Games, the initial goal of the World Youth Festival was to be more diverse not a celebration for a separate interest group but for all young people and students, regardless of social background or political engagement.

Regarding its content, the festival was an ambitious undertaking. Its programme combined cultural activities, sport games, leisure activities and political functions [Kansan Arkisto, Box WFDY 1947]. In the festival designers' desire to cover everything from culture to sports, from political and educational to recreational and entertainment activities, it was a unique enterprise. However, its shape, structure and agenda drew on existing forms of celebrations in socialist and capitalist countries.

The World Youth Festival was rooted in Soviet and socialist mass culture in many respects, yet it also differed from it a great deal. Like the May Day parades, Women's Day celebrations, Spartakiads or physical culture parades, the youth festival was organised top-down: its concept was created by youth league functionaries and participation was controlled by the organisers. Like pre-war Soviet festivals, the mixture of cultural and political dimensions, as well as the centrality of visual propaganda, constituted a central part of the event. Furthermore, the festival programme was based on the Soviet conception of culture as a mixture of high and popular cultures and criticism of western 'bourgeois' culture. The traditional conflict between high and low cultures was resolved by the Bolsheviks, who had apparently taken culture to a higher stage in comparison with bourgeois culture [Naimark, p. 398]. The main differences between the youth festivals and their Soviet equivalents were the context, audience and the aims. While Soviet mass festivals focused on Soviet society, the World Youth Festivals targeted the whole world: they were mostly organised outside Soviet borders and aimed at disseminating Soviet ideas on culture to 'others'.

The World Youth Festival was not the first international celebration organised by the communist youth movement. From the 1910s to the early 1940s, International Youth Week and International Youth Day served as international forums for youth celebration. Both were established by the Second Youth International, and continued to be organised by its successor, the Communist Youth International [Cornell, p. 17; Luza, p. 26-27]. During World War Two, the World Youth Council (the predecessor of the WFDY) revived this tradition by launching World Youth Week and World Youth Day. Both remained part of the WFDY's annual calendar in the postwar period: however, they never received as much attention as the World Youth Festival ${ }^{3}$. The IUS's annual celebration, International Students' Day, was celebrated on 17 November, which commemorated the Nazi repression

${ }^{3}$ While in the 1940s and 1950s coverage of the World Youth Festival in Soviet newspapers (Komsomols'kaia pravda, Pravda, Izvestiia) consisted of tens of articles per festival, World Youth Week was usually mentioned only once or twice. On World Youth Week, see: [Молодые борцы за мир]. 
of Czechoslovak students in 1939 during the occupation of Czechoslovakia [World Student News, 1947, No. 2].

Compared with the International and World Youth Weeks, the World Youth Festival was a much larger event regardless of the measurements one uses. Instead of one week, it lasted approximately two weeks: it gathered thousands of young people and the scope of combined events of culture and sport was something never seen before. Furthermore, while the International and World Youth Weeks had been celebrated separately in each country, the World Youth Festival provided a common place for young people from different countries to party together [Kansan Arkisto, Box WFDY 1945]. A festival that demanded travelling abroad made the participation of young people much more limited than in World Youth Week, which everybody had been able to celebrate at home. This was why the WFDY and the IUS encouraged national and local member organisations to organise national and local festivals prior to the World Youth Festival in order to highlight the forthcoming global celebration and give the wider masses the opportunity to manifest peace and friendship. National and local festivals functioned as arenas for selecting the best of the best to represent one's country at the World Youth Festival, which was meant to be the highlight of the WFDY's work [World Federation of Democratic Youth Bulletin, 1946, no. 4, 6].

Bolshevik mass festivals in the 1920s and 1930s played an important role in implementing the new Soviet culture and in legitimising the new regime. According to James von Geldern, "public celebrations become particularly meaningful during times of revolutionary change, when societies not only must project themselves into the future but must grapple with the legacy of their past" [von Geldern, p. 5-6]. In a similar fashion, the World Youth Festival functioned as an efficient stage for the USSR to promote its new status in the postwar world and strengthen its cultural order in new socialist states of Eastern Europe.

\section{Comparison with the World's Fairs and the Olympics}

When the designers of the World Youth Festival sat down to sketch what the new event would be like, they not only leaned on their experiences of celebration traditions in socialist and communist movements. What they might have regarded as a model international event was the World's Fair, especially its latest versions in Paris in 1937 and New York in 1939, where the Soviet pavilions had been enthusiastically welcomed. The resemblance of the youth festival to the Olympic Games in terms of composition and structure indicates that it also might have served as a model or inspiration for the youth event.

Those WFDY meetings and Komsomol reports that have been preserved in the archives and are available to researchers do not shed light on any concrete plans to imitate any of the aforementioned mega-events or other happenings. There is, nonetheless, evidence that the organisers kept track of other international youth events. During its first years (1946-1947), WFDY bulletins closely followed what happened in the Scout movement, especially the World Scout Jamborees: large international summer camps 
held regularly in different parts of the world from 1920 onwards. It is possible that the jamborees served as an early model for the World Youth Festival. At the very least, singing round a campfire and the special festival scarf and national uniforms that the delegates wore displayed similar elements to the Scout movement [World Federation of Democratic Youth Bulletin, No. 2, May/June 1946, p. 26]. Many qualities of the World Youth Festival, however, suggest that it was not merely a socialist version of the Jamboree.

Like the World's Fairs and the Olympic Games, the World Youth Festival sough to reach a global audience and form a recognisable cultural tradition with an established structure, name, message and visual representation [Gold J. R., Gold M. M., p. 17-47]. The sport historian Barbara Keys describes the Olympic movement as a universal form of communication, which is made of symbols and terms understandable to all sports enthusiasts around the world [Keys, p. 1-2]. Similarly, the World Youth Festival's core message of "peace and friendship", which was materialised in slogans, announcements, leaflets, articles, posters and the visual design of the festivals, constituted a special language, which became known both to the festival organisers and their opponents. Furthermore, the World Youth Festival shared the characteristic idea for mega-events of representing "the world in a village, creating a global public space for a limited time span". Instead of confining events to a limited group in official venues, the whole host city was employed as the stage, which meant that the impact of the games or festivities transcended far beyond the official delegates to the streets and squares of the celebrating city [Kaiser].

Similarities with the concept of the World's Fair were noted already in 1947 by William Attwood, who described the Prague Festival as a "world's fair in miniature' in The New York Times [The New York Times, 1947, 14 Sept.]. The World's Fairs, especially in the late nineteenth and early twentieth centuries, can be seen as manifestations of western cultural and technological modernity and dominant western cultural values. In a similar fashion, the World Youth Festivals promoted an idea of modernity: however, it was an alternative view largely shaped by the Soviet way of looking at the future. The national exhibitions and artistic competitions in particular resembled the World's Fairs in their attempt to demonstrate the best qualities of each nation's cultural traditions, while also providing forums for the organisers to disseminate their dominant cultural ideas [Munro]. While the World's Fairs emphasised industrial progress in the material and consumer cultures of the western industrial powers, the World Youth Festivals focused more on the immaterial and spiritual dimensions of culture and arts. Emphasising deep spiritual and intellectual, rather than material and shallow, dimensions of culture was typical for Soviet cultural conceptions that considered Soviet culture, rooted in long-standing Russian traditions, to be on a higher level than the western, bourgeois and decadent culture.

As for the structural and institutional dimensions, the closest capitalist model for the World Youth Festival was the Olympic Games. Like the Olympic Games, and modern sport in general, the World Youth Fes- 
tival was based on national representation but at the same time emphasised a universal message that surpassed nationalism [Keys, p. 2]. Both the Olympic Games and the World Youth Festivals occurred in regular cycles (the Olympics on a quadrennial basis and the Youth Festival on a biennial basis until 1959), national delegations or teams were visualised in national flags and uniforms and organisation was handled by international bodies (the international preparatory committee/the International Olympic Committee). They used recognisable symbols and shared similar quasi-religious rituals (e. g. the opening ceremony, releasing doves, a torch/festival relay and a special hymn) [Gold, Revill, p. 62]. At the early festivals, the organizers used either the white dove designed by Pablo Picasso for the World Peace Congresses or a picture where male and female figures held hands around a globe, similar to the United Nations' globe symbol [Deery]. A more direct mimicking also took place, like at the Berlin 1973 Festival, whose visual appearance came close to the design of the Munich Olympic Games [Schiller, p. 62-63].

The youth festival's resemblance of the Olympics is most obvious in the use of ceremonies. Numerous photographs and film material from the World Youth Festivals show how national delegations with national flags, and some dressed in national uniforms, marched in alphabetical order to the stadium, where the opening and closing ceremonies took place. The Olympic Games has come to be understood primarily as a sporting competition, in contrast to the thinking of the father of the modern Olympics, Pierre de Coubertin, who embraced the idea of mixing the intellectual and physical arts. The World Youth Festival, instead, more comprehensively embraced every part of human culture, and in this sense better resembled the conception of both the ancient and Coubertin's Olympics, combining "sports, the arts, technology and culture as mutually enriching and interrelated aspects of human life" [Gold, Revill, p. 59-83].

The World Youth Festival also resembled the Olympic Games in that the festival programme included international sports matches, whose sporting spectrum coincided with that of the Summer Olympics: this 'Olympic festival for students' was sometimes compared to the 'real Olympics' [World Student News, 1954, No. 12]. In the 1950s, before the Soviet Union joined the International Olympic Committee, the sporting games at the World Youth Festivals were important international sporting arenas for socialist athletes as well as sports fans, who wished to see socialist sports stars [Riordan, p. 73-74].

Despite the many similarities with the Olympic Games, Komsomol officials and leading figures in the WFDY hardly intended the World Youth Festival as a "counter-Olympic boycott", as John Hoberman has suggested [Hoberman, p. 18]. As Barbara Keys has shown, in the late 1940s, the Soviet Union was already prepared to enter the elite sporting world, which it had earlier opposed as alien to the workers' movement. When the World Youth Festival started, the Soviet Union was taking steps toward membership in the Olympic movement, sending an observer to the London games in 1948, 
and entering the games for the first time in Helsinki in 1952 [Keys, p. 3, 5, 169, 158-180; Прозуменщиков].

Rather than attempting to create a socialist parallel to the Olympic Games, the idea was to establish a completely new kind of a mega-event for the young generation. By mixing elements from the Olympic Games, World's Fairs, Scout jamborees, Soviet mass festival, artistic and sport competitions and political demonstrations, the World Youth Festival neither tried to become a Stalinist Olympics nor a Socialist World's Fair, but rather a universally valued international event for the youth. Like the Olympic Games and the World's Fairs that, according to Roche, contributed to the formation of 'international public culture' [Roche, p. 21-22], the World Youth Festival also had an impact on international public culture, albeit in a different way than its designers had initially intended.

\section{From a universal ideal to socialist internationalism}

In a post-war world where mutual distrust and suspicion were driving the former Allies into a new conflict, it was complicated to establish global forums that would be recognised by both sides. The original vision of unifying all young people regardless of political standpoint soon changed to a celebration of socialist internationalism and peace work in the Soviet style. In the West, the World Youth Festival never obtained the status of a universal gathering, instead becoming associated with the Soviet Union and communism. In a number of Western countries, the political establishment considered the festival as harmful communist influence on young people and students, which pushed them to make efforts to hinder travelling to the "communist rallies" and organise competing activities in Berlin (1951), Vienna and Helsinki (1962) [Krekola, Mikkonen]. Consequently, and against the publicly articulated aims of its founders, the festival did not become a shared forum for cultural exchange, but a battleground in the cultural Cold War between socialism and capitalism. Nigel Gould-Davis has argued that because of the threat of nuclear war, superpower rivalry moved to non-military forms, such as culture, the arts and sports [Gould-Davies, p. 195]. It also worked the other way around: attempts to build global institutions faced - at quite an early stage the superpower conflict that expanded from high politics to low politics and beyond in the late 1940s.

Despite that fact that the World Youth Festival did not become a universally recognized and accepted event, it came to be a significant gathering within the socialist world. Between 1947 and 1989, the festivals gathered $10,000-34,000$ participants from 71 to 162 countries. It was smaller than the World's Fairs (tens of millions of visitors), around the same size as the jamborees $(11,139-30,000)$ and larger than the Olympic Games $(669-8,319$ if only athletes are counted) [Rydell; Hill]. The most popular period was the 1950s, which is often considered the period when youth culture and the understanding of young people as a particular group of consumers emerged. The festival combined two things crucial for the postwar genera- 
tion: it spoke to their need to do something about world peace and offered an event particularly tailored to their age group. Thus, the World Youth Festival in the 1950s really hit the target: young people, especially from West and North European communist and democratic youth and student associations, poured into the festivals. Unlike Western propaganda sometimes had it, the hosts had no difficulties in finding enough people. Quite the contrary, there were often more people willing to come than the festivals could accommodate. The biggest delegation in the 1950s came from countries with relatively large communist parties, such as France, the UK and Finland [РГАНИ. Ф. 5. Оп. 28. Д. 363. Л. 10; Оп. 33. Д. 38. Л. 107].

World Youth Festivals, participating countries and delegates 1947-2017

$\begin{array}{lccc}\text { Year } & \text { Host } & \text { Countries } & \text { Participants } \\ 1947 & \text { Prague } & 71 & 17,000 \\ 1949 & \text { Budapest } & 82 & 10,400 \\ 1951 & \text { Berlin } & 104 & 26,000 \\ 1953 & \text { Bucharest } & 111 & 30,000 \\ 1955 & \text { Warsaw } & 115 & 26,000 \\ 1957 & \text { Moscow } & 131 & 34,000 \\ 1959 & \text { Vienna } & 112 & 18,000 \\ 1962 & \text { Helsinki } & 137 & 13,140 \\ 1965 & \text { Algiers } & \text { Cancelled } & - \\ 1966 & \text { Accra } & \text { Cancelled } & - \\ 1968 & \text { Sofia } & 138 & 20,000 \\ 1973 & \text { Berlin } & 140 & 30,000 \\ 1978 & \text { Havana } & 145 & 18,500 \\ 1985 & \text { Moscow } & 157 & 20,000 \\ 1989 & \text { Pyongyang } & 162 & 15,000 \\ 1997 & \text { Havana } & 136 & 12,325 \\ 2001 & \text { Algiers } & 151 & 7,127 \\ 2005 & \text { Caracas } & 144 & 17,000 \\ 2010 & \text { Tshwane } & 126 & 15,000 \\ 2013 & \text { Quito } & 80 & 8,500 \\ 2017 & \text { Sochi } & 180 & 20,000\end{array}$

The weakest part of the festival was the financing. Mega-events come with large costs, as was the case with the World Youth Festivals. Arranging a two-week event for 10-34,000 participants, tourists and journalists, as well as putting money into building and refining infrastructure (traffic, hotels, restaurants, stadia, concert halls), was a large investment for the host country. The need to reconstruct the urban environment was urgent in the immediate postwar years, when ruins still occupied the cityscape in Central European capitals. The popularity of the gathering also increased the costs, as it was largely based on subsidised participation fees and travel 
costs. In order to get participants from all over the world, the USSR and the wealthier socialist countries not only paid for most of the organisation, but also sponsored trips to the festivals through an International Festival Fund. The journeys of many delegations from Latin America and Africa were fully covered, but countries like Finland also received financial assistance in the form of cheap transport via Soviet Union [РГАСПИ. Ф. М-3. Оп. 15. Д. 36. Л. 63-65].

The festival ran more or less smoothly throughout the 1940s and 1950s, as there were enough socialist countries in Europe to organize the celebration in turns. After the largest and most successful festival was held in Moscow in 1957, the organizers attempted to widen the geopolitical reach of the event and brought it to two semi-neutral capitalist countries: Vienna in 1959 and Helsinki in 1962. Not only did these two festivals face aggressive anti-Soviet opposition in Austria and Finland, but they also demonstrated how difficult it was to arrange a mega-event of this size without support from the hosting state. Both in Austria and in Finland, the local organizational responsibility fell into the hands of communist organizations, while the state and city administration refused to support the events [Krekola, Mikkonen]. The lack of support from the political establishment became even more evident when the organisers attempted to export the festival to Africa: first in Algiers, Algeria, in 1965 and then in Accra, Ghana, a year later. Coup détats against the pro-Soviet governments in both countries forced the cancellation of the planned festivities and put an end to testing the events' geopolitical limits. It was now evident that the festival would continue, if was to continue, within secure socialist countries. The problem was, however, that the socialist world was much less coherent and united in the 1960s than it had been before as a result of the Sino-Soviet split and divergent views on how to build socialism, making it difficult to find loyal hosts [Rutter, p. 196-198]. The poor financial situation, too, caused the frequency of the festivals to decline, an indication of which was that the GDR and the USSR, the wealthiest states in the socialist bloc, got to host their second festivals in 1973 and 1985. And when Fidel Castro's Cuba, which had volunteered as a host a few times in the 1960s, was finally allowed to arrange the fete in Havana, the USSR paid the bill [РГАСПИ. М-1c. Оп. 1с. Д. 1113с. Л. 1-83].

Each of the World Youth Festivals held during the Cold War had a variety of impacts on the local, national and global levels. The festivals held soon after the war in Central Eastern Europe brought visible changes to the urban environment, with renovated buildings, repaired streets and new stadia. Some of the festivals, such as that in Moscow in 1957, became an important element in local and national shared memory, an event whose anniversaries have been celebrated with historical exhibitions in 2007 and 2017 [Три фестиваля]. The Vienna and Helsinki festivals, on the contrary, have not become part of national history writing in Austria and Finland. While the participants and hosts of the Helsinki Festival commemorated the 1962 festival in their worker's associations, it is either not mentioned at all or is placed in the context of Soviet foreign propaganda in national 
narratives of Cold War Finland. The prevailing narrative is still that Soviet Union forcefully exported the festival to Helsinki [Krekola, Mikkonen].

From the point of view of Soviet cultural diplomacy, the most long-lasting impact of the World Youth Festival as an institution lies in the strength and vitality of the concept. The organization was dependent on financial support from the USSR, but the World Youth Festival always managed to get into the news in non-communist media, keeping the festival in people's minds even if the message was not always favourable for the socialist world.

The Soviet system created one of the largest youth events in world history, an event that won support among the young especially in the aftermath of World War Two. Establishing a new global event and managing to keep it going throughout the Cold War benefited Soviet cultural diplomacy goals in many respects. An attractive event that gathered thousands of participants from all over the globe demonstrated the strength of the Soviet-led democratic youth movement and its ability to network and speak to youth. The Soviet Union's Cold War opponents also realised this. The fact that non-leftist newspapers and youth organizations in the US and Western Europe vigorously boycotted the festival implies that it was considered an effective way of influencing young people. In the 1950s, there were even plans to create a youth gathering of the "free world", a competitor to the World Youth Festival, but it never materialised [Telegram from the United States delegation at the North Atlantic Council Ministerial meeting to the Department of State, 17.12.1955, 43]. The fact that the World Youth Festival was closely connected to the USSR and socialist system meant that suspicions about communist dominance over the festivals cast a shadow on its aim to act as a universal institution. The other side of the coin was that the festival organization (the WFDY, the IUS and national preparatory committees) could quite freely manifest an agenda that favoured Soviet foreign policy. In this way, the whole festival institution, not only those held in Moscow in 1957 and 1985, became infrastructure for Soviet cultural diplomacy.

The World Youth Festival was a distinctively Cold War event. Its vitality was based on the financial and organizational structures of the socialist system. When that system ceased to exist at the beginning of the 1990s, the festival, too, saw a radical change. The festival is still being organized, but its global cultural and political importance is merely a weak shadow of its Cold War predecessors. While in the Cold War the World Youth Festivals were in the news around the world, the post-1991 celebrations have hardly been mentioned outside the host countries and anti-imperialist leftist youth groups. The legacy of the festival lives on in Russia, where the Moscow festivals of 1957 and 1985 have left cultural imprints in the form of street names and shared memories. The memory of the youth festivals has also endured within workers' associations in the UK and Finland. The most recent version of the World Youth Festival shows that while the event 
has survived the collapse of its main financial supporter, the USSR, it has not flourished in quite the same way as during the Cold War. The Nineteenth World Youth Festival in Sochi in 2017 was widely reported in Russia, but it received only marginal attention in the global media.

\section{Список литературы}

Молодые борцы за мир // Правда. 1952. 21 мая. С. 1.

Мошняга В. П. Всемирная федерация демократической молодежи. М. : Молодая гвардия, 1976. $144 \mathrm{c}$.

Попов А. Участие СССР в организации и проведении Всемирных фестивалей молодежи и студентов // Советская культурная дипломатия в условиях холодной войны : 1945-1989. М. : РОССПЭН, 2018. С. 121-169.

Прозуменщиков М. Ю. Большой спорт и большая политика. М. : РОССПЭН, 2004. $462 \mathrm{c}$.

РГАНИ. Ф. 5. ОП. 28. Д. 363; Оп. 33. Д. 38.

РГАСПИ. Ф. М-3. Оп. 15. Д. 36; Ф. М-1с. Оп. 1с. Д. 1113с.

Три фестиваля // Музей Москвы : [офиц. сайт]. 2017. URL: https://mosmuseum.ru/ exhibitions/p/tri-festivalya/ (дата обращения: 06.07.2020).

Applebaum R. The Friendship Project: Socialist Internationalism in the Soviet Union and Czechoslovakia in the 1950s and 1960s // Slavic Rev. Vol. 74. 2015. No. 3. P. 484-507. DOI 10.5612/slavicreview.74.3.484.

Babiracki P. Soviet Soft Power in Poland. Culture and the Making of Stalin's New Empire, 1943-1957. Chapel Hill : Univ. of North Carolina Press, 2015. 344 p.

Barghoorn F C. Soviet Foreign Propaganda. Princeton : Princeton Univ. Press, 1964. $329 \mathrm{p}$.

Clarke D. Theorising the Role of Cultural Products in Cultural Diplomacy from a Cultural Studies Perspective // Intern. J. of Cultural Policy. Vol. 22. 2016. No. 2. P. 147-163. DOI 10.1080/10286632.2014.958481.

Cornell R. Youth and Communism. An Historical Analysis of International Communist Youth Movements. N. Y. : Walker and Company, 1965. 239 p.

David-Fox M. Showcasing the Great Experiment. Cultural Diplomacy and Western Visitors to the Soviet Union, 1921-1941. N. Y. : Oxford Univ. Press, 2012. 448 p.

Deery P. The Dove Flies East: Whitehall, Warsaw and the 1950 World Peace Congress // Australian J. of Politics and History. Vol. 48. 2002. No. 4. P. 449-468. DOI 10.1111/14678497.00270.

Geldern J. von. Bolshevik Festivals, 1917-1920. Berkeley : Univ. of California Press, 1993. $316 \mathrm{p}$.

Gold J. R., Gold M. M. Athens to Athens: The Summer Olympics, 1896-2004 // Olympic Cities. City Agendas, Planning, and the World's Games, 1896-2012 / eds. by J. R. Gold, M. M. Gold. L. : Routledge, 2007. P. 15-47.

Gold M. M., Revill G. The Cultural Olympiads: Reviving the Panegyric // Olympic Cities. City Agendas, Planning, and the World's Games, 1896-2012 / eds. by J. R. Gold, M. M. Gold. L. : Routledge, 2007. P. 59-83.

Gould-Davies N. The Logic of Soviet Cultural Diplomacy // Diplomatic History. Vol. 27. 2003. No. 2. P. 193-214. DOI 10.1111/1467-7709.00347.

Griswold W. Cultures and Societies in a Changing World. Thousand Oaks : Pine Forge Press, 2004. $193 \mathrm{p}$.

Hoberman J. The Olympic Crisis. Sport, Politics and the Moral Order. New Rochelle : Aristide D. Caratzaz, 1986. 167 p.

Kaiser W. The Great Derby Race: Strategies of Cultural Representation at NineteenthCentury World Exhibitions // Culture and International History / eds. by J. C. E. GienowHecht, F. Schumacher. N. Y. : Berghahn Books, 2003. P. 45-59. 
Kansan Arkisto (People's Archive). Reijo Viitanen's Collection. Box WFDY 1947; Box WFDY 1945.

Keys B. Globalizing Sport: National Rivalry and International Community in the 1930s. Cambridge : Harvard Univ. Press, 2006. 274 p.

Koivunen P. Performing Peace and Friendship. The World Youth Festival as a Tool of Soviet Cultural Diplomacy, 1947-1957 : PhD Diss. Tampere : [S. n.], 2013. 372 p.

Kotek J. Students and the Cold War. L. : Macmillan, 1996. 279 p.

Krekola J., Mikkonen S. Backlash of the Free World. The US Presence at the World Youth Festival in Helsinki, 1962 // Scandinavian J. of History. Vol. 36. 2011. No. 2. P. 231-256. DOI 10.1080/03468755.2011.565566.

Luza R. History of the International Socialist Youth Movement. Leyden : A. W. Sijthoff, 1970. $336 \mathrm{p}$.

Müller M. What Makes an Event a Mega-Event? Definitions and Sizes // Leisure Studies. Vol. 34. 2015. No. 6. P. 627-642. DOI 10.1080/02614367.2014.993333.

Munro L. Investigating World's Fairs: An Historiography // Studies in Latin Am. Popular Culture. Vol. 28. 2010. P. 80-94. DOI 10.1353/sla.0.0001.

Naimark N. M. The Russians in Germany. A History of the Soviet Zone of Occupation, 1945-1949. Cambridge : Belknap Press : Harvard Univ. Press, 1995. 586 p.

Riordan J. Elite Sport Policy in East and West // The Politics of Sport / ed. by L. Allison. Manchester : Manchester Univ. Press, 1986. P. 66-89.

Roche M. Mega-events and Modernity: Olympics, Expos and the Growth of Global Culture. L. : Routledge, 2000. 281 p.

Roth-Ey K. "Loose Girls" on the Loose? : Sex, Propaganda and the 1957 Youth Festival // Women in the Khrushchev Era / eds. by M. Ilic, S. E. Reid, L. Attwood. Basingstoke : Palgrave Macmillan, 2004. P. 75-95.

Rutter N. Look Left, Drive Right: Internationalism at the 1968 World Youth Festival // Socialist Sixties. Crossing Borders in the Second World / eds. by A. E. Gorsuch, D. Koenker. Indiana : Indiana Univ. Press, 2013. P. 193-212.

Rydell R. World of Fairs: The Century-of-progress Expositions. Chicago : Univ. of Chicago Press, 1993. 269 p.

Schiller K. Communism, Youth and Sport. The 1973 World Youth Festival in East Berlin // Sport and the Transformation of Modern Europe / eds. by A. Tomlinson et al. L. ; N. Y. : Routledge, 2011. P. 50-66.

Taylor K. Let's Twist Again: Youth and Leisure in Socialist Bulgaria. Wien : Lit Verlag, 2006. $248 \mathrm{p}$.

World Federation of Democratic Youth Bulletin. 1946. No. 2, 4.

World Student News. 1947. No. 2. 1954. No. 12.

\section{References}

Applebaum, R. (2015). The Friendship Project: Socialist Internationalism in the Soviet Union and Czechoslovakia in the 1950s and 1960s. In Slavic Rev. Vol. 74. No. 3, pp. 484-507. DOI 10.5612/slavicreview.74.3.484.

Babiracki, P. (2015). Soviet Soft Power in Poland. Culture and the Making of Stalin's New Empire, 1943-1957. Chapel Hill, Univ. of North Carolina Press. 344 p. $329 \mathrm{p}$.

Barghoorn, F C. (1964). Soviet Foreign Propaganda. Princeton, Princeton Univ. Press.

Clarke, D. (2016). Theorising the Role of Cultural Products in Cultural Diplomacy from a Cultural Studies Perspective. In Intern. J. of Cultural Policy. Vol. 22. No. 2, pp. 147-163. DOI 10.1080/10286632.2014.958481.

Cornell, R. (1965). Youth and Communism. An Historical Analysis of International Communist Youth Movements. N. Y., Walker and Company. 239 p.

David-Fox, M. (2012). Showcasing the Great Experiment. Cultural Diplomacy and Western Visitors to the Soviet Union, 1921-1941. N. Y., Oxford Univ. Press. 448 p. 
Deery, P. (2002). The Dove Flies East: Whitehall, Warsaw and the 1950 World Peace Congress. In Australian J. of Politics and History. Vol. 48. No. 4, pp. 449-468. DOI 10.1111/14678497.00270.

Geldern, J. von. (1993). Bolshevik Festivals, 1917-1920. Berkeley, Univ. of California Press. 316 p.

Gold, J. R., Gold, M. M. (2007). Athens to Athens: The Summer Olympics, 1896-2004. In Gold, J. R., Gold, M. M. (Eds.). Olympic Cities. City Agendas, Planning, and the World's Games, 1896-2012. L., Routledge, pp. 15-47.

Gold, M. M., Revill, G. (2007). The Cultural Olympiads: Reviving the Panegyric. In Gold, J. R., Gold, M. M. (Eds.). Olympic Cities. City Agendas, Planning, and the World's Games, 1896-2012. L., Routledge, pp. 59-83.

Gould-Davies, N. (2003). The Logic of Soviet Cultural Diplomacy. In Diplomatic History. Vol. 27. No. 2, pp. 193-214. DOI 10.1111/1467-7709.00347.

Griswold, W. (2004). Cultures and Societies in a Changing World. Thousand Oaks, Pine Forge Press. 193 p.

Hoberman, J. (1986). The Olympic Crisis. Sport, Politics and the Moral Order. New Rochelle, Aristide D. Caratzaz. 167 p.

Kaiser, W. (2003). The Great Derby Race: Strategies of Cultural Representation at Nineteenth-Century World Exhibitions. In Gienow-Hecht, J. C. E., Schumacher, F. (Eds.). Culture and International History. N. Y., Berghahn Books, pp. 45-59.

Kansan Arkisto (People's Archive). Reijo Viitanen's Collection. Box WFDY 1947; Box WFDY 1945.

Keys, B. (2006). Globalizing Sport: National Rivalry and International Community in the 1930s. Cambridge, Harvard Univ. Press. 274 p.

Koivunen, P. (2013). Performing Peace and Friendship. The World Youth Festival as a Tool of Soviet Cultural Diplomacy, 1947-1957. PhD Diss. Tampere, S. n. 372 p.

Kotek, J. (1996). Students and the Cold War. L., Macmillan. 279 p.

Krekola, J., Mikkonen, S. (2011). Backlash of the Free World. The US Presence at the World Youth Festival in Helsinki, 1962. In Scandinavian J. of History. Vol. 36. No. 2, pp. 231-256. DOI 10.1080/03468755.2011.565566.

Luza, R. (1970). History of the International Socialist Youth Movement. Leyden, A. W. Sijthoff. 336 p.

Molodye bortsy za mir [Young Peace Activists]. (1952). In Pravda. 21 May, p. 1.

Moshnyaga, V. P. (1976). Vsemirnaya federatsiya demokraticheskoi molodezhi [World Federation of Democratic Youth]. Moscow, Molodaya gvardiya. 144 p.

Müller, M. (2015). What Makes an Event a Mega-Event? Definitions and Sizes. In Leisure Studies. Vol. 34. No. 6, pp. 627-642. DOI 10.1080/02614367.2014.993333.

Munro, L. (2010). Investigating World's Fairs: An Historiography. In Studies in Latin Am. Popular Culture. Vol. 28, pp. 80-94. DOI 10.1353/sla.0.0001.

Naimark, N. M. (1995). The Russians in Germany. A History of the Soviet Zone of Occupation, 1945-1949. Cambridge, Belknap Press of Harvard Univ. Press. 586 p.

Popov, A. (2018). Uchastie SSSR v organizatsii i provedenii Vsemirnykh festivalei molodezhi i studentov [The Participation of the USSR in the Organisation and Hosting of World Festivals of Youth and Students]. In Sovetskaya kul'turnaya diplomatiya v usloviyakh kholodnoi voiny. 1945-1989. Moscow, ROSSPEN, pp. 121-169.

Prozumenshchikov, M. Yu. (2004). Bol'shoi sport i bol'shaya politika [Big Sport and Big Politics]. Moscow, ROSSPEN. $462 \mathrm{p}$.

RGANI [Russian State Archive of Contemporary History]. Stock 5. List 28. Dos. 363; List 33. Dos. 38.

RGASPI [Russian State Archive of Social-Political History]. Stock M-3. List 15. Dos. 36; Stock M-1c. List 1c. Dos. 1113c.

Riordan, J. (1986). Elite Sport Policy in East and West. In Allison, L. (Ed.). The Politics of Sport. Manchester, Manchester Univ. Press, pp. 66-89. 
Roche, M. (2000). Mega-Events and Modernity: Olympics, Expos and the Growth of Global Culture. L., Routledge. 281 p.

Roth-Ey, K. (2004). "Loose Girls" on the Loose? Sex, Propaganda and the 1957 Youth Festival. In Ilic, M., Reid, S. E., Attwood, L. (Eds.). Women in the Khrushchev Era. Basingstoke, Palgrave Macmillan, pp. 75-95.

Rutter, N. (2013). Look Left, Drive Right: Internationalism at the 1968 World Youth Festival. In Gorsuch, A. E., Koenker, D. (Eds.). Socialist Sixties. Crossing Borders in the Second World. Indiana, Indiana Univ. Press, pp. 193-212.

Rydell, R. (1993). World of Fairs: The Century-of-Progress Expositions. Chicago, Univ. of Chicago Press. 269 p.

Schiller, K. (2011). Communism, Youth and Sport. The 1973 World Youth Festival in East Berlin. In Tomlinson, A. et al. (Ed.). Sport and the Transformation of Modern Europe. L., N. Y., Routledge, pp. 50-66.

Taylor, K. (2006). Let's Twist Again: Youth and Leisure in Socialist Bulgaria. Wien, Lit Verlag. 248 p.

Tri festivalya [Three Festivals]. (2017). In Muzei Moskvy [official website]. URL: https:// mosmuseum.ru/exhibitions/p/tri-festivalya/ (accessed: 06.07.2020).

World Federation of Democratic Youth Bulletin (1946). No. 2, 4.

World Student News (1947). No. 2. (1954). No. 12.

The article was submitted on 24.01.2020 